\title{
PENGARUH PEMBERIAN KEFIR SUSU SAPI TERHADAP KADAR TRIGLISERIDA TIKUS JANTAN SPRAGUE DAWLEY
}

\author{
Fika Noviandini Putri Sari, Adriyan Pramono*) \\ Program Studi Ilmu Gizi Fakultas Kedokteran Universitas Diponegoro \\ Jl.Dr.Sutomo No.14, Semarang, Telp (024) 8453708, Email : gizifk@undip.ac.id
}

\begin{abstract}
Background :Triglyceride are major lipid in foods and fat deposits. Increased triglyceride levels lead to increased risk factors of metabolic syndrome and cardiovascular disease. One other potential ways of diet management to lower triglyceride levels is by consuming probiotic product. Milk kefir is one of those probiotic products. Milk's kefir contains CLA (Conjugated Linoleic Acid) in which can lowering serum triglycerides because it can increasing lipolysis and beta oksidation of fatty acid.

Methods : Pre and post test with control group design was conducted in this study. The 28 rats were divided into 4 groups, which is one control group given standard food and 3 treatment group given additional per oral diet of cow's milk kefir as much $1.5 \mathrm{ml} /$ day for treatment I, $2 \mathrm{ml} /$ day for treatment $\mathrm{II}$, and $3 \mathrm{ml} /$ day for treatment $I I I$ for 15 days. Levels of triglycerides were determined using GPO_PAP method. Data were analyzed by paired t test and Kruskal Wallis test.

Result : Triglyceride level of each groups elevated. After intervention, triglyceride levels in both control group and treatment group of various dose of kefir decreased. However, Kruskal Wallis test showed no significant differences in triglyceride level compared to all groups $(p=0,529)$.

Conclusion : There was no effect of kefir to triglyceride level.
\end{abstract}

Keyword : triglyceride levels; kefir

\section{ABSTRAK}

Latar Belakang : Trigliserida merupakan lipid utama pada simpanan lemak dan di dalam makanan. Peningkatan kadar trigliserida dapat menyebabkan peningkatan faktor risiko sindrom metabolik dan penyakit kardiovaskuler. Salah satu cara potensial lain dalam pengaturan diet untuk menurunkan trigliserida adalah dengan mengkonsumsi produk probiotik.Salah satu jenis produk probiotik adalah kefir susu sapi. Kefir susu sapi mengandung CLA (Conjugated Linoleic Acid) yang berperan dalam menurunkan trigliserida dengan cara meningkatkan lipolisis dan beta oksidasi asam lemak.

Metoda : Penelitian ini menggunakan metode pre and post test with randomized contol group design. Subyek terdiri dari 28 ekor tikus yang dibagi menjadi 4 kelompok, yaitu 1 kelompok kontrol, yang hanya diberi pakan standar dan 3 kelompok perlakuan yang diberi tambahan diet kefir susu sapi peroral sebanyak 1,5 ml/hari untuk kelompok perlakuan I, $2 \mathrm{ml}$ /hari untuk kelompok perlakuan II, dan $3 \mathrm{ml} /$ hari untuk kelompok perlakuan III selama 15 hari. Analisis kadar trigliserida menggunakan metode GPO-PAP. Data yang diperoleh dianalisis menggunakan uji paired t test dan uji Kruskal Wallis.

Hasil : Setelah pemberian pakan tinggi kolesterol kadar trigliserida setiap kelompok meningkat. Setelah intervensi, penurunan kadar trigliserida terjadi pada kelompok kontrol maupun kelompok yang diberikan perlakuan kefir susu sapi dengan berbagai dosis. Namun, uji Kruskal Wallis menunjukkan tidak ada pengaruh kefir tehadap penurunan kadar trigliserida pada semua kelompok $(p=0,529)$

Kesimpulan : Tidak ada pengaruh kefir terhadap kadar trigliserida.

Kata kunci : kadar trigliserida; kefir

\section{PENDAHULUAN}

Trigliserida merupakan lipid utama pada simpanan lemak dan di dalam makanan. Lebih dari 95\% lemak dari makanan disimpan dalam tubuh dalam bentuk trigliserida. ${ }^{1}$ Peningkatan kadar trigliserida serum menyebabkan peningkatan faktor risiko sindrom metabolik dan penyakit kardiovaskuler. Penelitian meta-analisis pada ribuan pasien menunjukkan bahwa peningkatan 1
mmol/L trigliserida serum meningkatkan risiko penyakit kardiovaskuler sebanyak $30 \%$ pada pria dan $75 \%$ pada wanita. ${ }^{2}$

Berbagai cara dapat dilakukan untuk menurunkan kadar trigliserida dalam darah diantaranya dengan menggunakan obat - obatan dan pengaturan diet seperti mengurangi konsumsi lemak jenuh, mengurangi konsumsi kolesterol dan mengurangi konsumsi karbohidrat refined. ${ }^{3}$ Salah

\footnotetext{
${ }^{*}$ Penulis Penanggungjawab
} 
satu cara potensial lain dalam pengaturan diet yang dianjurkan kepada masyarakat adalah dengan mengkonsumsi produk probiotik.

Produk probiotik termasuk salah satu dari makanan fungsional. Salah satu produk probiotik yang telah berkembang adalah susu fermentasi. Beberapa penelitian melaporkan bahwa susu fermentasi selain dapat menurunkan kolesterol juga dapat menurunkan kadar trigliserida. ${ }^{4,5,6,7}$ Satu dari beberapa penelitian tersebut melaporkan bahwa penurunan trigliserida ini diduga karena kandungan CLA (Conjugated Linoleic Acid) yang merupakan hasil metabolit dari susu fermentasi. ${ }^{5}$ CLA diduga dapat meningkatkan lipolisis dan beta oksidasi asam lemak sehingga pembentukan kadar trigliserida dapat dikurangi. ${ }^{8,9}$ Salah satu produk susu fermentasi yang diduga berpotensi untuk menurunkan kadar trigliserida adalah kefir susu sapi karena dilaporkan dalam sebuah penelitian bahwa kefir juga mengandung CLA (Conjugated Linoleic Acid). ${ }^{10}$

Berdasarkan uraian diatas peneliti tertarik untuk meneliti pengaruh kefir terhadap kadar trigliserida untuk melihat seberapa besar potensi kefir dalam menurunkan kadar trigliserida. Penelitian ini menggunakan hewan percobaan sebagai subyek. Hewan percobaan yang digunakan adalah Ratus norvegicus galur Sprague Dawley yang peka terhadap pengaruh lipid jika diberikan perlakuan pada dietnya.

\section{METODE}

Penelitian ini menggunakan rancangan true experiment dengan pre post test with randomized control group design. Perlakuannya adalah dengan pemberian kefir susu sapi, sedangkan keluarannya adalah kadar trigliserida.

Subjek penelitian yang digunakan adalah tikus jantan galur Sprague Dawley umur 6 minggu dengan berat 80 - 100 gram yang diperoleh dari Laboratorium Hewan Percobaan PPOMN Badan POM Jakarta.

Pada penelitian ini terdapat tiga kelompok perlakuan dan satu kelompok kontrol. Perhitungan jumlah sampel minimal mempergunakan rumus besar sampel eksperimental dari Federerr dimana $(\mathrm{t}-1)(\mathrm{r}-1) \geq 15, \mathrm{t}$ adalah jumlah perlakuan dan $\mathrm{r}$ adalah jumlah hewan coba tiap kelompok perlakuan. Penelitian dengan 3 kelompok perlakuan dan 1 kelompok kontrol, sehingga $\mathrm{t}=4$, (4-1)(r-1) $\geq 15 \rightarrow r \geq 6$. Antisipasi drop out pada tiap kelompok $10 \%$ sehingga didapatkan subjek masing-masing kelompok sebanyak 7 ekor. Pada penelitian ini terdapat 4 kelompok yaitu kelompok kontrol (pemberian pakan standar + air minum ad libitium), kelompok perlakuan 1 (pakan standar + kefir 1,5 ml), kelompok perlakuan 2 (pakan standar + kefir $2 \mathrm{ml}$ ), dan kelompok perlakuan 3 (pakan standar + kefir $3 \mathrm{ml}$ ).

Tikus dipelihara dalam kandang individual berukuran $41,5 \times 29,5 \times 20 \mathrm{~cm}$ pada ruangan dengan suhu berkisar $20-22^{\circ} \mathrm{C}$, kelembaban $60-$ $70 \%$ dan siklus pencahayaan pada malam hari gelap dan pada siang hari mendapat penerangan sinar matahari. Seluruh subjek penelitian diadaptasi terlebih dahulu selama 7 hari dan diberi pakan standar sebanyak 50 gram/hari dan minum ad libitium. Pakan standar rodentia terbuat dari tepung jagung $31 \%$, bungkil gandum (wheaf pollard) 20\%, bungkil kedelai (soy bean meal) $15 \%$, tepung ikan (fish meal) 12\%, bungkil kelapa (coconut oil) 8\%, bungkil wijen (sesame meal) 5\%, tepung daun singkong (cassava leaf) $8 \%$, vitamin (premix). Dalam 100 gram pakan standar mengandung protein $22,87 \%$, lemak $0,44 \%$, karbohidrat $32,67 \%$, serat kasar 7,68\% dan kalori 226,12 kal.

Selanjutnya diberi pakan yang terdiri atas pakan standar dan otak sapi selama 15 hari. Otak sapi yang diberikan merupakan otak sapi yang telah dikukus dan diblender. Selanjutnya pemberian pada hewan coba dilakukan dengan cara sonde sebanyak $2 \mathrm{ml} /$ hari selama 15 hari. Selanjutnya subyek diberi perlakuan pemberian kefir selama 15 hari.

Kefir yang digunakan berbahan dasar susu sapi yang diperoleh dari peternak sapi didaerah ungaran. Pembuatan kefir dimulai dari susu sapi dipasteurisasi pada suhu $85^{\circ} \mathrm{C}$ selama 30 menit, didinginkan dalam wadah berbahan gelas dan ditambahkan butir kefir dengan dosis starter sebanyak 7\%. Campuran susu dan butir kefir diinkubasi pada suhu kamar selama 24 jam hingga terjadi penggumpalan sempurna. Selanjutnya, kefir disaring untuk memisahkan butir kefir.

Tabel 1. Hasil Analisis Proksimat Susu Sapi dan Kefir

\begin{tabular}{ccc}
\hline Parameter & \multicolumn{2}{c}{ Hasil } \\
\cline { 2 - 3 } & Susu Sapi & Kefir \\
\hline Kadar Karbohidrat (\%) & 5,788 & 1,403 \\
Kadar Lemak (\%) & 4,156 & 1,904 \\
\hline
\end{tabular}




\begin{tabular}{ccc}
\hline Kadar Protein (\%) & 3,519 & 1,796 \\
Kadar air (\%) & 85,751 & 94,301 \\
Kadar abu (\%) & 0,785 & 0,596 \\
\hline
\end{tabular}

Analisis kadar trigliserida serum dilakukan 3 kali,yaitu sebelum pemberian pakan standar dan otak sapi, 15 hari setelah pemberian pakan standar dan otak sapi , serta 15 hari setelah pemberian pakan standar dan kefir. Darah diambil dari plexus pre-orbitalis tikus Sprague dawley dan dimasukkan ke dalam tabung bersih, kemudian darah dicentrifuge dengan kecepatan $3000 \mathrm{rpm}$ selama 5 menit untuk mendapatkan serumnya. Kadar trigliserida serum darah tikus diperiksa dengan metode GPO-PAP di Balai Besar Laboratorium Kesehatan Jakarta (BBLK) Kementerian Kesehatan Jakarta.

Data yang diperoleh dilakukan entry, editing, dan coding pada program komputer. Data dianalisis secara statistik menggunakan program komputer SPSS 17. Data tersebut diuji normalitasnya dengan uji Shapiro-Wilk. Hasilnya data terdistribusi tidak normal sehingga dilakukan transformasi data agar data menjadi normal.
Setelah ditransformasi data kembali diuji normalitasnya dengan Shapiro-Wilk dan didapatkan data yang telah menjadi normal. Kemudian dilakukan uji beda parametrik paired $t$ test antara kadar trigliserida sebelum dan sesudah pemberian pakan standar dan otak sapi. Uji parametrik paired $t$ test juga dilakukan antara kadar trigliserida serum sebelum dan sesudah intervensi dengan kefir. Perbedaan pengaruh dari keempat kelompok perlakuan dianalisis menggunakan uji statistik non parametrik Kruskal Wallis karena data tidak berdistribusi dengan normal walaupun sudah dilakukan transformasi data.

\section{HASIL}

Perubahan Kadar Trigliserida Sebelum dan Sesudah Pemberian Pakan Standar dan Otak Sapi

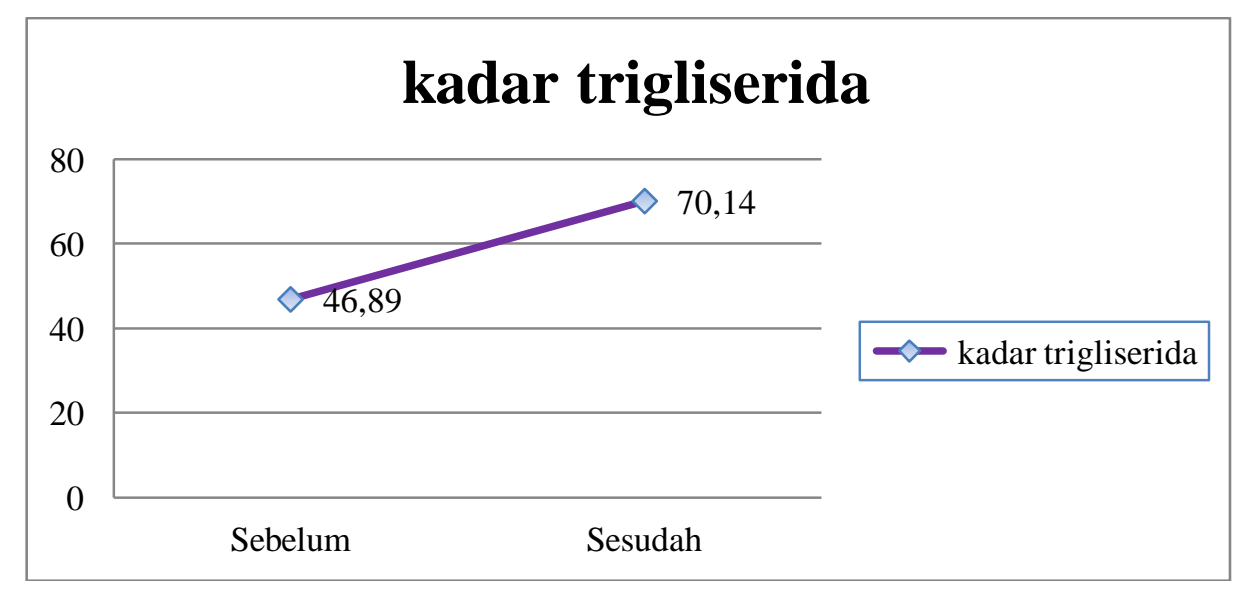

Gambar 1. Kadar Trigliserida Sebelum dan Setelah Pemberian Pakan Tnggi Kolesterol

Berdasarkan Gambar 1. rerata kadar trigliserida tikus sebelum pemberian pakan standar dan otak sapi adalah 46,89 $\mathrm{mg} / \mathrm{dl}$ dan sesudah pemberian pakan standar dan otak sapi mengalami peningkatan yang signifikan $(p=0,000)$ yaitu sebesar 70,14 mg/dl . Rerata kenaikan kadar trigliserida adalah $49,58 \%$.

Perubahan Kadar Trigliserida Sebelum dan Setelah Pemberian Kefir

Tabel 2. Perubahan kadar trigliserida antar kelompok perlakuan setelah intervensi

\begin{tabular}{|c|c|c|c|c|c|c|c|c|}
\hline \multirow[b]{2}{*}{$\begin{array}{c}\text { Kelompo } \\
\mathrm{k}\end{array}$} & \multicolumn{3}{|c|}{ Sebelum } & \multicolumn{3}{|c|}{ Sesudah } & \multirow{2}{*}{$\underset{\text { median }}{\Delta}$} & \multirow[b]{2}{*}{$P$} \\
\hline & Min & $\begin{array}{c}\mathrm{Ma} \\
\mathrm{x}\end{array}$ & Median & Min & Max & Median & & \\
\hline K & 39 & 104 & $\begin{array}{c}68 \pm 21,9 \\
2\end{array}$ & 30 & 58 & $38 \pm 9,84^{*}$ & 30 & $0,529 * *$ \\
\hline $\mathrm{P} 1$ & 35 & 87 & $76 \pm 18,0$ & 19 & 48 & $35 \pm 10,78$ & 41 & \\
\hline
\end{tabular}




\begin{tabular}{lllccccc}
\hline P2 & 61 & 104 & $81+14,7$ & 15 & 47 & $35 \pm 9,60^{*}$ & 46 \\
P3 & 41 & 98 & $58 \pm 21,41$ & 18 & 49 & $33 \pm 9,91^{*}$ & 25 \\
\hline
\end{tabular}

$*$ ada perbedaan yang bermakna antara sebelum dan sesudah intervensi $(p<0,05)$

** tidak ada perbedaan yang bermakna antara tiap-tiap kelompok $(p>0,05)$

Tabel 2. menunjukkan tidak ada pengaruh kefir terhadap kadar trigliserida.

\section{PEMBAHASAN}

\section{Kadar Trigliserida Setelah Pemberian Pakan Standar dan Otak Sapi}

Hasil penelitian ini menunjukkan adanya peningkatan kadar trigliserida yang signifikan $(p<0,05)$ yaitu sebesar 49,58 \%. Peningkatan kadar trigliserida dikarenakan kandungan asam lemak jenuh pada otak sapi. ${ }^{11}$ Saat mengonsumsi makanan tinggi lemak jenuh, asam lemak jenuh dari makanan akan berikatan dengan gliserol membentuk trigliserida. Pada jalur eksogen, trigliserida diangkut dari usus dalam bentuk kilomikron. Kilomikron dilepas oleh sel usus melalui penyatuan vakuola sekretorik dengan membran sel, melintasi ruang antar sel menuju sistem limfatik. Kilomikron ini akan membawanya ke dalam aliran darah. Kemudian trigliserida dalam kilomikron mengalami penguraian oleh enzim lipoprotein lipase sehingga terbentuk asam lemak bebas dan kilomikron remnant. Asam lemak bebas akan menembus jaringan lemak untuk diubah menjadi trigliserida kembali sebagai cadangan energi. Sedangkan kilomikron remnant akan dimetabolisme dalam hati sehingga menghasilkan kolesterol bebas. ${ }^{12}$

\section{Kadar Trigliserida Setelah Intervensi Kefir}

Penelitian ini diharapkan kefir mampu menurunkan kadar trigliserida melalui mekanisme penurunan trigliserida oleh CLA yang diduga mampu meningkatkan lipolisis dan beta oksidasi asam lemak dan CLA juga dapat mereduksi asam lemak pada jaringan adiposa. ${ }^{8,9}$ Asam lemak merupakan salah satu komponen pembentuk trigliserida. Bila asam lemak dapat dikurangi, maka pembentukan trigliserida juga akan berkurang. Namun, hasil penelitian ini tidak dapat membuktikan bahwa perlakuan kefir berkontribusi dalam menurunkan trigliserida. Hal ini dibuktikan dengan setelah masa intervensi kefir, baik kelompok kontrol maupun kelompok perlakuan mengalami penurunan kadar trigliserida secara signifikan dengan penurunan paling tinggi terjadi pada kelompok P2 lalu diikuti oleh kelompok P1, $\mathrm{K}$ dan P3.

Penurunan ini dapat disebabkan oleh penghentian pemberian otak sapi pada tiap kelompok. Penghentian pemberian otak sapi membuat konsumsi lemak jenuh subjek berkurang. Asupan lemak jenuh yang berkurang ini dapat mempengaruhi turunnya kadar trigliserida subjek saat pengambilan darah terakhir. ${ }^{4}$ Kandungan serat dalam pakan standar juga menjadi faktor lain dalam menurunnya kadar trigliserida pada setiap kelompok. Trigliserida dalam usus halus dihidrolisis menjadi asam lemak dan gliserol, asam lemak ini akan diikat oleh serat sehingga tidak dapat membentuk micelle dan tidak dapat diabsorpsi dalam usus halus, kemudian akan menuju usus besar untuk diekskresi dalam bentuk feses atau degradasi oleh bakteri usus. ${ }^{13,14}$

Kandungan asam amino lisin dan metionin yang berasal dari tepung ikan, bungkil kedelai dan bungkil kelapa pada pakan standar merupakan prekursor pembentukkan karnitin. Di dalam mitokondria, karnitin merangsang proses $\beta$ oksidasi asam lemak rantai panjang sehingga pembentukan kadar trigliserida dapat dikurangi. ${ }^{15,16}$ Kandungan $\beta$-conglycinin pada bungkil kedelai diduga juga dapat berpengaruh pada kadar trigliserida. Di hati, $\beta$-oxidasi asam lemak ditingkatkan oleh $\beta$-conglycinin dan di sisi lain aktifitas fatty acid synthase berkurang. Efek penurunan kadar trigliserida oleh $\beta$-conglycinin juga melalui peningkatan jumlah ekskresi trigliserida di feses. ${ }^{17} \mathrm{Di}$ dalam protein kedelai, isoflavon yang berfungsi sebagai antioksidan dapat menurunkan absorpsi kolesterol dan trigliserida oleh usus dan kemungkinan juga mengurangi reabsorpsi asam empedu yang dapat menyebabkan peningkatan sekresi sterol netral dan asam empedu dalam feses. ${ }^{18}$

Dalam penelitian ini selisih penurunan kadar trigliserida kelompok P1,P2 dan P3 tidak berbeda nyata dengan kadar kolesterol total kelompok K $(p>0,05)$. Diduga kandungan lemak dan karbohidrat dalam pakan dan kefir menjadi salah satu penyebab tidak bermaknanya perbedaan tersebut. ${ }^{7}$ Komposisi lemak dan karbohidrat kefir tergantung dari susu yang digunakan sebagai bahan bakunya. ${ }^{19}$ Bahan baku kefir dalam penelitian ini adalah susu sapi yang mengandung kadar lemak $4,156 \%$ dan karbohidrat $5,788 \%$. Kefir yang 
dihasilkan mengandung kadar lemak sebesar $1,904 \%$ dan karbohidrat sebesar $1,403 \%$. Sedangkan dalam 100 gram pakan standar mengandung $0,44 \%$ lemak dan $32,67 \%$ karbohidrat. Asam lemak yang berasal dari lemak yang dikonsumsi dapat berikatan dengan gliserol dan membentuk trigliserida. Karbohidrat dalam metabolisme dapat diubah menjadi asam lemak oleh hati kemudian asam lemak ini berikatan dengan gliserol sehingga membentuk trigliserida. $^{12,20}$

\section{SIMPULAN DAN SARAN}

Penurunan trigliserida juga terjadi pada kelompok kontrol yang tidak diberikan perlakuan dengan kefir sehingga hasil dalam penelitian ini tidak terbukti bahwa perlakuan kefir dapat menurunkan kadar trigliserida.

Perlu penelitian lebih lanjut terkait pengaruh berbagai konsentrasi kefir grain dengan volume yang sama terhadap kadar trigliserida dengan menggunakan kefir berbahan baku susu rendah lemak.

\section{DAFTAR PUSTAKA}

1. Kathleen MB, Peter AM. Metabolisme Asilgliserol \& Sfingolipid. Dalam: Murray RK, Granner DK, Mayes PA, Rodwell VW,editor. Biokimia harper. $27^{\text {th }}$ ed. Jakarta: EGC; 2009 p.217.

2. Hokanson JE, Austin MA. Plasma triglyceride level is a risk factor for cardiovascular disease independent of high - density lipoprotein cholesterol level : a meta - analysis of population - based prospective studies. J. Cardiovasc Risk. 1996 Apr 3; (2):213-9.

3. Sanjer J Robins. Triglycerides - a variable cardiovascular risk factor. US Endocrine Disease. 2006.

4. Ari Y. Pengaruh Pemberian Susu Fermentasi Lactobacillus Casei Strain Shirota Terhadap Perubahan Kadar Fraksi Lipid Serum Tikus Hiperkolesterolemi (Tesis). Semarang: Universitas Diponegoro. 2004.

5. Dewi RN, Eni H, Y Marsono.Efek metabolit susu fermentasi terhadap profil lipid pada tikus Sprague Dawley. Yogyakarta : Universitas Gajah Mada. 2003.

6. Je-Reui L, Sheng-Yao W, Ming-Ju C, Hsiao-Ling C, Pei-Ying Y, Chin-Wen L. Hypocholesterolaemic Effects of Milk-Kefir and Soyamilk-Kefir in Cholesterol-Fed Hamsters. British Journal of Nutrition. 2006; 95;p.939-46.

7. St-Onge MP Et Al. Kefir Consumption Does Not Alter Plasma Lipid Levels Or Cholesterol Fractional Synthesis Rates Relative To Milk In Hyperlipidemic Men: A Randomized Controlled Trial. Biomed Central. 2002; 2:1.
8. George S Kelly. Conjugated Linoleic Acid.Thorne Research. 2001.

9. Williams, Iane. C.L.A the essential nutrient for cutting cancer risk, reducing body fat and providing antioxidant properties.Woodland Publishing, Inc. 1997.

10. Judiono. Potensi Kefir Bening Sebagai Antidiabetes Dikaji dari Status Glikemik, Antioksidan, Respon Imun dan Regenerasi Sel B Pancreas pada Tius Strain Wistar Hiperglikemia Diinduksi Streptozotocin [Disertasi]. Semarang: Universitas Diponegoro, 2011.

11. Slamet R. Pengaruh Pemberian Yogurt Kedelai Hitam (Black Soygurt) Terhadap Profil Lipid Tikus Hiperkolesterolemia. Semarang : Universitas Diponegoro. 2011.

12. Kathleen MB, Peter AM. Pengangkutan dan Penyimpanan Lipid. Dalam: Murray RK, Granner DK, Mayes PA, Rodwell VW,editor. Biokimia harper. $27^{\text {th }}$ ed. Jakarta: EGC; 2009 p. $225-237$.

13. Macdonald, Ian. Diet and Triglyceride Metabolism. J. clin. Path. 26, suppl. (Ass. Clin Path.), 5, 22-25

14. Lairon D, Arnault N, Betrais S, Planells R, Clero E., Herchberg S, et al. Dietary fiber intake and risk factors for cardiovascular disease in French adults. Am J Clin Nutr [serial online] 2005 [dikutip pada 15 April 2012]; 82: 1185-94. Available from: URL HYPERLINK http://www.ajcn.org

15. Eli R, Alfajri, Deri A, Dwi T, Surya SP. Upaya Penurunan Lemak Tubuh Ayam Broiler Melalui Penambahan Metionin dan Lisin Sebagai Prekursor Karnitin dalam Ransum. Padang : Uniersitas Andalas. 2010.

16. Sitompul, S. Analisis Asam Amino Dalam Tepung Ikan dan Bungkil Kedelai. Buletin Teknik Pertanian vol. 9. 2004;(1):p.33-37.

17. Tatsuya M, Keiko K, Kiyoko N, Reiko U, Tadashi $\mathrm{O}$, Shigeru $\mathrm{U}$ et al. Soybean $\beta$-conglycinin Diet Supresses Serum Triglyceride Levels in Normal and Genetically Obese Mice by Induction of $\beta$ Oxidation, Downregulation of Fatty Acid Synthase, and Inhibition of Triglyceride Absorption. Biochem. 2004; 68 (2), p.352-359.

18. Pradita EK. Potensi sari kedelai hitam terhadap kadar trigliserida tikus putih (Rattus Norvegicus) dengan diet tinggi lemak. Lampung :Universitas Airlangga. 2011.

19. Manik ES. Kajian Konsentrasi Kefir Grain dan Lama Simpan dalam Refrigerator terhadap Kualitas Kimiawi Kefir Rendah Lemak. Jurnal Ilmu-ilmu Peternakan;21(1):p.24-30.

20. Susan E. Macronutrients: Carbohydrates, Proteins, and Lipids. Dalam : Kathleen M, Sylvia ES. Krause's Food and Nutrition Therapy 11th ed. Philadelphia: Saunders. 2000. p. 49, p.56. 